\title{
FASCIOLIASIS IN RELATIVES OF PATIENTS WITH Fasciola hepatica INFECTION IN PERU
}

\author{
Luis MARCOS(1), Vicente MACO(1), Angélica TERASHIMA(1), Frine SAMALVIDES(1), José R. ESPINOZA(2) \& Eduardo GOTUZZO(1)
}

\begin{abstract}
SUMMARY
High prevalence rates of human fascioliasis have been described in several regions of Peru. We surveyed 20 families in an endemic area of Peru in order to determine the proportion of infection with $F$. hepatica in relatives of diagnosed subjects and in order to identify associated risk factors. The study included feces and blood samples of 93 subjects. Ages ranged from one to 53 (mean $=18.6 ; \mathrm{SD}=14.2)$. The overall prevalence of fascioliasis by fecal examinations was $33.3 \%(\mathrm{n}=83)$ and by serology, $51.9 \%$ $(\mathrm{n}=86)$. The prevalence in age group I ( $\leq 19$ years old) by coprological and serological tests was $61.4 \%$ and $75.9 \%$, respectively; in group II (> 19 years old) $15.4 \%$ and $37.5 \%$. The main associated risk factor with fascioliasis was eating salads $(\mathrm{OR}=3.29, \mathrm{CI}$ $=1.2-9.0, p=0.02)$. In conclusion, human fascioliasis is highly prevalent in the relatives of index cases and the most significant risk factor of acquiring fascioliasis in the family is eating salads in endemic areas.
\end{abstract}

KEYWORDS: Fascioliasis; Relatives; Index case; Risk factors; Salads; Peru.

\section{INTRODUCTION}

Fascioliasis is a parasitic disease caused by the fluke Fasciola hepatica (Linnaeus, 1758). The disease is acquired for the most part by eating watercress, other vegetables or by drinking water contaminated with metacercariae $e^{5,20}$. Human fascioliasis is a serious health problem in many countries, the number of reported cases have increased significantly worldwide since $1980^{7}$.

There are many endemic areas throughout Peru, where the highest prevalence rates range from $8 \%$ in Cajamarca ${ }^{14}, 28.3 \%$ in the Mantaro Valley $^{18}$, and $35 \%$ in Puno by stool examinations ${ }^{10}$; and up to $36.3 \%$ by serological tests in Jauja ${ }^{18}$. These results suggest that Peru is one of the countries with the widest regional distribution of human fascioliasis brought on by $F$. hepatica in the world. A rural population of almost eight million people is estimated at risk in this country ${ }^{24}$. Human fascioliasis should no longer be considered as a secondary zoonosis in Peru, but as an important human parasitic disease.

Although fascioliasis occurs at all ages, the most affected are endemic-area school-children ${ }^{8}$. Most of the cases reported from hospitals or health centers are adults, probably due to the increasing complications seen in this age group, such as acute cholecystitis, biliary obstruction or cholangitis ${ }^{2,4,12}$.

One of the remarkable clinical characteristics of human fascioliasis in endemic areas is the relative absence of gastrointestinal symptoms ${ }^{19}$.
Some cases are diagnosed during surgery, when adult parasites cause bile duct obstruction or hepatic dysfunction ${ }^{1,11,23}$. The percentage of patients who develop these complications is unknown. Early diagnosis and treatment might avoid expensive and risky procedures. The early detection of most human fascioliasis should be one of the priorities of Fasciola control programs.

Two case reports show a significant proportion of parasitosis in relatives of index cases with fascioliasis ${ }^{21}$. Half of the relatives of two patients with fascioliasis in Spain also were infected ${ }^{22}$, and in Germany a family of four acquired the infection, after eating raw vegetables during a visit to an endemic area; while only one of them required medical attention ${ }^{3}$.

In order to determine the infection rate or grade of $F$. hepatica in relation to member of index case, and in order to identify the epidemiological and clinical characteristics, we surveyed 20 families from an endemic area.

\section{MATERIALS AND METHODS}

Study area: The study was carried out in the District of Asillo, Province of Azángaro, Department of Puno, at an altitude of 3,970 meters above sea level (1447'03' LS; 75²1'13" LO), which occupies about $392.38 \mathrm{~km}^{2}$. Most of the homes in the district lack drinking water and electricity. The majority of the population is engaged in farming and livestock raising.

(1) Instituto de Medicina Tropical Alexander von Humboldt (IMT AvH), Universidad Peruana Cayetano Heredia (UPCH), Lima, Perú.

(2) Unidad de Biotecnología Molecular, Laboratorios de Investigación y Desarrollo de Ciencia y Tecnología, Universidad Peruana Cayetano Heredia (UPCH), Lima, Perú.

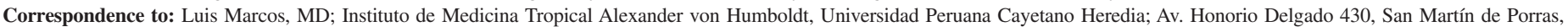
Lima 31, Perú. Telephone: 511-3821021. Fax: 511-3821021. Email: luismarcos@rcp.net.pe 
Study population: Asillo has a total population of 2,853 inhabitants who live in extreme poverty. The index case was defined as a person with $F$. hepatica infection diagnosed in a previous epidemiological study by our group (unpublished data). The families were all taken from index cases.

Subjects and families: A total of 20 families were included in the study; each family having between two and 13 members. We divided the ages of subjects into two groups: group I, under 19 years; and group II, over 19 years of age. The criteria of this division was to compare the high prevalence of fascioliasis found in subjects under 19 years old in other epidemiological study near this region ${ }^{9}$, and the group over 19 years that we studied.

Clinical-epidemiological interview and physical examination: The questionnaire used local colloquial language and included demographic data, sources of food and water, types of vegetables, house characteristics (including number and type of animals), defecation habits, as well as general and gastrointestinal symptoms which might be associated with $F$. hepatica infection.

Fecal samples: Stools were collected on two consecutive days. Coprological tests were carried out in 83 subjects. We were unable to obtain stool from 10 subjects. The samples were placed in $10 \%$ formalin on the same day that they were passed and then transported to the Parasitology Laboratory, Instituto de Medicina Tropical Alexander von Humboldt (IMTAvH) of the Universidad Peruana Cayetano Heredia for processing. Stools were examined by the Rapid Sedimentation Technique described by Lumbreras $(\mathrm{RST})^{16}$ and the Kato-Katz Technique (KKT) ${ }^{13}$. The RST is a routinely used technique in the IMT AvH because of its low cost and high sensitivity ${ }^{17}$.

Blood sample: Five $\mathrm{mL}$ of venous blood were obtained from 86 consenting subjects. We were unable to obtain blood from seven subjects. Samples were centrifuged the same day, the sera were separated and transported to Lima at $-4{ }^{\circ} \mathrm{C}$ to be stored frozen at $-20^{\circ} \mathrm{C}$, until being assayed by the Fas2-ELISA as originally described $^{6,17}$.

Statistical analysis: SPSS 9.0 for Windows (Copyright $(\subset)$ SPSS Inc, 1989-1999) was used. The analysis consisted of a univariate descriptive analysis that calculated frequencies and percentages for categorical variables. For continuous variables, the means and standard deviations were calculated. Bivariate analysis was applied for categorical variables with $X^{2}$ or Ficher's exact test; Student's $t$ test was used for continuous variables. A value of $\mathrm{p}<0.05$ was considered as the critical level of significance. Odds ratio (OR), confidence intervals 95\% (CI) and $p$ values were calculated. Subsequently, stepwise conditional logistic regression was used to determine independent potential risk factors that are associated to $F$. hepatica infection.

Ethical considerations: The study was approved by the Institutional Ethics Committee of the UPCH. Written informed consents were obtained from the parents or guardians and assent from children, respectively; all of whom were informed about the nature of the study, the benefits and the risks. All positive patients were treated with triclabendazole.

\section{RESULTS}

The general characteristics of subjects are shown in Table 1. There were no significant differences in the prevalence of fascioliasis between males and females $(p>0.05)$. The results of prevalence by coprological - serological tests, and univariate -multivariate analysis are shown in Tables 2 and 3, respectively.

Table 1

General characteristics of subjects of the 20 families

\begin{tabular}{lccc}
\hline & Group I (n) & Group II (n) & Total (n) \\
\hline Total (number of subjects) & 61 & 32 & 93 \\
Gender & 32 & 12 & 44 \\
$\quad$ Male & 29 & 20 & 49 \\
Female & $1-19$ & $20-53$ & $1-53$ \\
Age (Range in years) & $9.1 ; 3.6$ & $36.8 ; 6.9$ & $18.6 ; 14.2$ \\
Mean, standard deviation &
\end{tabular}

Group I: $\leq 19$ years old; Group II: > 19 years old.

Table 2

Comparative results between coprological / serological percentages and groups I / II

\begin{tabular}{lcc}
\hline & Coprology & Serology \\
\hline Age groups & & \\
Group I: $1-19$ years $(\mathrm{n}=61)$ & $61.4 \%(\mathrm{n}=57)^{\dagger}$ & $75.9 \%(\mathrm{n}=54)$ \\
Group II: $>19$ years $(\mathrm{n}=32)$ & $15.4 \%(\mathrm{n}=26)$ & $37.5 \%(\mathrm{n}=32)$ \\
Total $(\mathrm{n}=93)$ & $33.3 \%(\mathrm{n}=83)$ & $51.9 \%(\mathrm{n}=86)$ \\
\hline
\end{tabular}

$\dagger$ There were differences statistically in coprology/serology and groups I/II $(p=0.000)$.

Table 3

Epidemiological survey of $F$. hepatica infection in 20 families from Peru: results of univariate and regression analysis

\begin{tabular}{lccc}
\hline $\begin{array}{l}\text { Variables associated with } \\
F . \text { hepatica } \text { infection }\end{array}$ & OR & CI & P value \\
\hline Univariate analysis & & & \\
Water supply from cannals & 3.89 & $1.14-13.26$ & 0.024 \\
Eating salads & 3.55 & $1.33-9.46$ & 0.01 \\
Drinking alfalfa juice & 2.67 & $1.04-6.89$ & 0.04 \\
Defecate in silos & 0.24 & $0.06-0.88$ & 0.024 \\
\hline Logistic regression analysis & & & \\
Eating salads & 3.29 & $1.2-9.0$ & 0.02 \\
\hline
\end{tabular}

$\mathrm{OR}=$ odd ratio $; \mathrm{CI}=$ confidence interval.

In the clinical picture, there were two variables associated with fascioliasis, asthenia $\left(\mathrm{X}^{2}=5.07, p=0.024\right)$ and dizziness $\left(\mathrm{X}^{2}=6.69, p\right.$ $=0.01$ ), among those considered as important clinical characteristics.

\section{DISCUSSION}

We found a high prevalence of human fascioliasis in the relatives 
of index cases. More than $50 \%$ of children in the index cases' families were infected with $F$. hepatica in this district, up to $75.9 \%$ in relatives under 19 years old. In a family of 11 people, nine had fascioliasis. Therefore, it is justified to rule out $F$. hepatica infection in all relatives of a person with this parasitosis.

In endemic areas, children are the most affected age-group, and groups under 19 years of age usually present the highest infection rates, which is consistent with our results ${ }^{9}$. There was no significant difference between males and females, which is explained by the similarity of diet in both genders, as has been observed in other studies ${ }^{9,10}$.

Univariate analysis found an association between four variables and fascioliasis: drinking water supply from canals, eating raw vegetable salads, drinking alfalfa juice and defecating in silos. Since this population has no municipal running potabilized water, it is likely that water from irrigation canals could be a significant risk factor. Viable metacercariae have been found in natural water supplies of endemic $\operatorname{areas}^{20}$

We also found that drinking alfalfa juice was a risk factor for human fascioliasis. Drinking alfalfa juice is a common habit in areas of Peru where fascioliasis is endemic. A recent study found that drinking "emolientes" (warm vegetable beverages made mainly from alfalfa and watercress) was associated with human fascioliasis in a population of the Peruvian central Andes ${ }^{18}$. An older study found metacercariae in $10.5 \%$ of emolientes sold by vendors in a popular market in the city of Arequipa, in southern Peru ${ }^{15}$. Therefore, we can suggest that alfalfa juice may be an important risk factor, not only in this region; but also in many other areas throughout Peru as well.

Apparently, good hygienic habits decrease the risk of acquiring fascioliasis. People with good hygienic habits may be less likely to contract the infection, may having less contact with the contaminated environment than those with poor hygienic habits.

Eating raw salads was associated with fascioliasis in both univariate and logistic regression analyses. This population's diet is for the most part made up carbohydrates from tubers and legumes; while many other vegetables such as tomatoes, lettuces, onions, carrots, among others, are eaten just the same. These crops are irrigated by water canals, which may contain metacercariae. Perhaps in one or more of the edible portions of these vegetables, metacercariae are encysted, and which might explain why some cases of non-endemic areas are seen in hospitals, where fascioliasis is seldom diagnosed. Most of these patients deny having eaten watercress or having drunk alfalfa juice, but they have eaten salads.

Among the clinical symptoms, only asthenia and dizziness were statistically associated with $F$. hepatica infection. These are not likely to be caused by fascioliasis, which mainly produces gastrointestinal symptoms. We believe that most of the people surveyed were asymptomatic, when they were interviewed. The presence of multiple intestinal parasitic infections may have confused the clinical picture in most of the population.

We can conclude that human fascioliasis is found in a high proportion to the relatives of index cases, and this should be taken into account when fascioliasis is detected; it is usually present in most members of a family. Eating raw vegetable salads is a significant risk factor through which families may acquire the infection in endemic areas. It is recommended that patients presenting abdominal pain and low to high eosinophilia, who have recently visited an area endemic for $F$. hepatica, should be carefully studied so as to rule out this parasitosis and the study could be expanded to include other travel companions or family members as well.

\section{RESUMEN}

\section{Fasciolosis en familiares de pacientes con infección por Fasciola hepatica en el Perú}

Altas tasas de fasciolosis humana han sido descritas en varias regiones del Perú. Estudiamos 20 familias en una área endémica del Perú para determinar la proporción de infección con $F$. hepatica en los familiares de los sujetos diagnosticados y para identificar factores de riesgo asociados. El estudio incluyó un total de 93 sujetos, quienes contribuyeron con muestras de heces y sangre. Las edades comprendieron desde 1 a 53 años (media $=18.6$; DS $=14.2)$. La prevalencia general de fasciolosis por exámenes de heces fue $33.3 \%$ $(n=83)$ y por serología, $51.9 \%(n=86)$. La prevalencia en el grupo de edad I ( $\leq 19$ años de edad) por pruebas coprológicas y serológicas fueron $61.4 \%$ y $75.9 \%$, respectivamente; en el grupo II (> 19 años de edad) $15.4 \%$ y $37.5 \%$. El principal factor de riesgo asociado con fasciolosis fue comer ensaladas $(\mathrm{OR}=3.29$, $\mathrm{IC}=1.2-9.0, \mathrm{p}=0.02$ ). En conclusión, la fasciolosis humana es altamente prevalente en familiares de los casos índices y el factor de riesgo más significante para adquirirla en la familia es comer ensaladas en las áreas endémicas.

\section{ACKNOWLEDGMENTS}

We would like to express our thanks to Víctor Neyra, Unidad de Biotecnología Molecular, Facultad de Ciencias y Filosofía Alberto Cazorla Talleri, Universidad Peruana Cayetano Heredia (UPCH) for his help in the processing of sera; Dr. Raúl Tello, Marco Canales and Carmen Quijano, Laboratorio de Parasitología, Instituto de Medicina Tropical Alexander von Humboldt, UPCH for their help in the processing of stool samples; Dr. César Wegener, Director of the Hospital Regional of Azángaro, Puno, Perú, for storing blood samples; Dr. Abdías Hurtado, President of CTAR - Puno, Perú, for providing transportation for the authors to the study area. To Dr. Humberto Guerra, M.D., Ph.D., Dr.Med., Profesor de Medicina, Instituto de Medicina Tropical Alexander von Humboldt, Universidad Peruana Cayetano Heredia for his assistance reviewing this paper.

\section{REFERENCES}

1. ALMENDRAS-JARAMILLO, M.; RIVERA-MEDINA, J.; SEIJAS-MOGROVEJO, J. \& ALMENDRAS-JARAMILLO, K. - Hepatic fascioliasis in children: uncommon clinical manifestations. Arq. Gastroent. (S. Paulo), 34: 241-247, 1997.

2. ARJONA, R.; RIANCHO, J.A.; AGUADO, J.M.; SALESA, R. \& GONZALEZ-MACIAS, J. - Fascioliasis in developed countries: a review of classic and aberrant forms of the disease. Medicine (Baltimore), 74: 13-23, 1995.

3. BECHTEL, U.; FEUCHT, H.E.; HELD, E.; VOGL, T. \& NOTHDURFT, H.D. - Fasciola hepatica infection in a family: diagnosis and therapy. Dtsch. med. Wschr., 117: 978-982, 1992. 


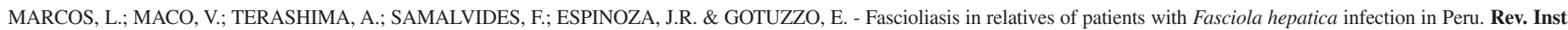
Med. trop. S. Paulo, 47(4):219-222, 2005.

4. BLANCAS, G.; TERASHIMA, A.; MAGUIÑA, C. et al. - Fasciolosis humana y compromiso gastrointestinal: estudio de 277 pacientes en el Hospital Nacional Cayetano Heredia, 1970-2002. Rev. Gastroent. Perú, 24:143-157, 2002.

5. CHEN, M.G. \& MOTT, K.E. - Progress in assessment of morbidity due to Fasciola hepatica infection: a review of recent literature. Trop. Dis. Bull., 87 (suppl.): R1-R38, 1990.

6. CORDOVA, M.; REATEGUI, L. \& ESPINOZA, J. - Immunodiagnosis of human fascioliasis with Fasciola hepatica cysteine proteinases. Trans. roy. Soc. trop. Med. Hyg., 93: 54-57, 1999.

7. ESTEBAN, J.G.; BARGUES, M.D. \& MAS-COMA, S. - Geographical distribution, diagnosis and treatment of human fascioliasis: a review. Res. Rev. Parasit., 58: 1342, 1998.

8. ESTEBAN, J.G.; FLORES, A.; ANGLES, R. et al. - A population-based coprological study of human fascioliasis in a hyperendemic area of the Bolivian Altiplano. Trop. Med. Int. Hlth., 2: 695-699, 1997.

9. ESTEBAN, J.G.; FLORES, A.; ANGLES, R. \& MAS-COMA, S. - High endemicity of human fascioliasis between Lake Titicaca and La Paz valley, Bolivia. Trans. roy. Soc. trop. Med. Hyg., 93: 151-156, 1999.

10. ESTEBAN, J.G.; GONZALEZ, C.; BARGUES, M.D. et al. - High fascioliasis infection in children linked to a man-made irrigation zone in Perú. Trop. Med. Int. HIth, 7: 339-348, 2002

11. HEREDIA, D.; BORDAS, J.M.; MONDELO, F. \& RODES, J. - Gallbladder fascioliasis in a patient with liver cirrhosis. Med. clín. (Barcelona), 82: 768-770, 1984.

12. JIMENEZ, J.; LOJA, D.; RUIZ, E. et al. - Fascioliasis hepática ¿un problema diagnóstico?. Rev. Gastroent. Perú, 21: 148-152, 2001.

13. KATZ, N.; CHAVEZ, A. \& PELLEGRINO, J. - A simple device for quantitative stool thick-smear technique in schistosomiasis mansoni. Rev. Inst. Med. trop. S. Paulo, 14: $397-409,1972$

14. KNOBLOCH, J.; DELGADO, E.; ÁlVAREZ, A.; REYMANN, U. \& BIALEK, R. Human fascioliasis in Cajamarca/Perú. I. Diagnostic methods and treatment with praziquantel. Trop. Med. Parasit., 36: 88-90, 1985.
15. LEGUIA, P.G. - La distomatosis en el Perú. In: ZALDÍVAR, S.R. Zooparásitos de interés veterinario en el Perú. Lima, Minsa, 1991. p. 3-5.

16. LUMBRERAS, H.; CANTELLA, R. \& BURGA, R. - Acerca de un procedimiento de sedimentación rápida para investigar huevos de Fasciola hepatica en las heces, su evaluación y uso en el campo. Rev. méd. peru., 31: 167-174, 1962.

17. MACO, V.; MARCOS, L.A.; TERASHIMA, A. et al. - Fas2-ELISA y la técnica de sedimentación rápida modificada por Lumbreras en el diagnóstico de la infección por Fasciola hepatica. Rev. méd. Herediana, 13: 49-57, 2002.

18. MARCOS, L; MACO, V.; TERASHIMA, A. et al. - Hiperendemicidad de fasciolosis humana en el Valle del Mantaro: factores de riesgo para la infección por Fasciola hepatica. Rev. Gastroent. Perú, 24: 158-164, 2004.

19. MARCOS, L.A.; MACO, V.; TERASHIMA, A.; SAMALVIDES, F. \& GOTUZZO, E. Características clínicas de la infección crónica por Fasciola hepatica en niños. Rev. Gastroent. Perú, 22: 228-233, 2002.

20. MAS-COMA, M.S.; ESTEBAN, J.G. \& BARGUES, M.D. - Epidemiology of human fascioliasis: a review and proposed new classification. Bull. Wld. Hlth. Org., 77: 340-346, 1999.

21. PETITHORY, J.C. - Familial eosinophilia: contribution of parasitology to its diagnosis Bull. Acad. nat. Méd. (Paris), 182: 1823-1838, 1998.

22. RODRIGUEZ, J.; CANUT, A.; BREZMES, M.F. et al. - Familial outbreaks of fascioliasis: usefulness of serologic investigation by enzyme immunoassay. Rev. clín. esp., 198: 33-35, 1998.

23. SANCHEZ-SOSA, S.; ROJAS-ORTEGA, S.; REED-SAN ROMAN, G. \& TORRESSANTANA, M.A. - Massive hepatobiliary fascioliasis. Rev. Gastroent. Méx., 65: 179-183, 2000.

24. WORLD HEALTH ORGANIZATION - Control of foodborne trematode infections Report of a WHO Expert Committee. Wld. Hlth. Org. techn. Rep. Ser., (849), 1995.

Received: 17 February 2005

Accepted: 31 May 2005 